\title{
TRAINING THE USE OF INDONESIA THE TOURISM DIVISION OF THE TOURISM OFFICE OF BAUBAU CITY
}

\author{
Suryanti ${ }^{1}$ \\ ${ }^{1}$ Indonesian Language and Literature Education Study Program Faculty of Teacher Training \\ and Education Universitas Muhammadiyah Buton \\ e-mail: suryanti042516@gmail.com
}

\begin{abstract}
Language is a character. The polite language reflects the polite person. Vice versa. The habit of using good language will affect human character. In other words, learning and acquiring Indonesian is the process of how a person can speak. Acquisition of language that can be in the office sometimes also occurs naturally. Language acquisition is usually natural without realizing that someone has acquired language and unconsciously he uses language in communication. This counseling aims to increase employee knowledge in the tourism office and find out the variety and function of the language used in communicating with fellow employees at the Tourism Office in Baubau City. The results of the counseling revealed that in the use of communicative Indonesian with a function and situation approach. This is a starting point in the concept of using Indonesian. Furthermore, the variety of languages used is non-standard languages because it turns out that this type of language variety is far more communicative than standard languages (standard) given that this is the use of language for employees at the Tourism Office of Baubau City so that the use of specific terms of tourism does not have to be translated in Indonesia.
\end{abstract}

Keywords: Use of Indonesian Language, Tourism

\section{A. Introduction}

Language not only functions as a communication tool but also as a means of introducing culture, society and natural wealth belonging to the nation and the State of Indonesia.

The tourism route needs to be utilized for recognition, a feeling of love and the need to understand and use Indonesian. Whereas through domestic tourism can also be used to understand and realize the wealth of local languages which is a wealth that needs to be raised together. In accepting and providing services to foreign tourists, it is necessary to have proficiency and foreign language skills to facilitate and facilitate communication. But keep in mind beforehand that quite a lot of foreign tourists who come to visit who want to use the opportunity to facilitate the ability to speak Indonesian 
Tourism efforts which are basically aimed at the main values and industrial and economic benefits are also necessary so that they do not become obstacles to the use of the functions and position of languages in Indonesia.

As a tourism office, one of which is engaged in tourism emphasizes improving the quality of Human Resources in the field of tourism and hospitality, technically operational and managerial. As described above, that language also plays an important role in the field of tourism, in addition to the use of Indonesian, the efforts made are to learn and master the use of foreign languages and Indonesian language is continuously carried out. Besides English which is a foreign language that must be learned there are also a number of languages including Indonesian, French, Japanese, Mandarin.

Speaking of various languages one thing that is very important in this discussion there are a variety of written and spoken languages. Variety of written languages tends to standard standard languages, on the contrary the variety of spoken languages is influenced by situations and conditions in the field. Do we use standard language in conducting conversations with others, especially in formal situations? does when we speak standard language make the language we use communicative?

\section{B. Problems}

Based on this, the problems in this service are (1) What is the level of Indonesian language needs in tourism in the Baubau City tourism office staff (2) What is the function and variety of Indonesian language use in tourism.

\section{Implementation Method}

The method in this activity is about learning Indonesian for tourism based on descriptive methods with reference to a qualitative approach. Data analysis was performed using qualitative descriptive methods (Hardin, et al., 2019: 3). A qualitative approach involving oral and written data in the language community. The information referred to is the language source that comes from the use of Indonesian by Tourism office employees when they interact with guests. By using a qualitative method because it is easier when dealing with existing realities, this method presents directly the nature of the relationship between presenters and tourism office employees and also uses this method more sensitive and 
younger to adjust to the many sharpening of mutual influence and to the pattern of values faced.

This descriptive method aims to provide a systematic, factual and accurate descriptive of the data, nature and relationship of the phenomena encountered. Furthermore, the service will be carried out by inviting a number of Baubau City government employees and hotel managers or managers to be held at the Indonesian Language Usage Training in the Tourism Office of the City of Baubau. This is done to make tourism office employees and hotel managers able to provide maximum service and make employees comfortable when interacting with guests from outside as well as in carrying out all tasks. The training process lasted for 2 days. The scheme below is the flow of the work stages that will be carried out in this activity:

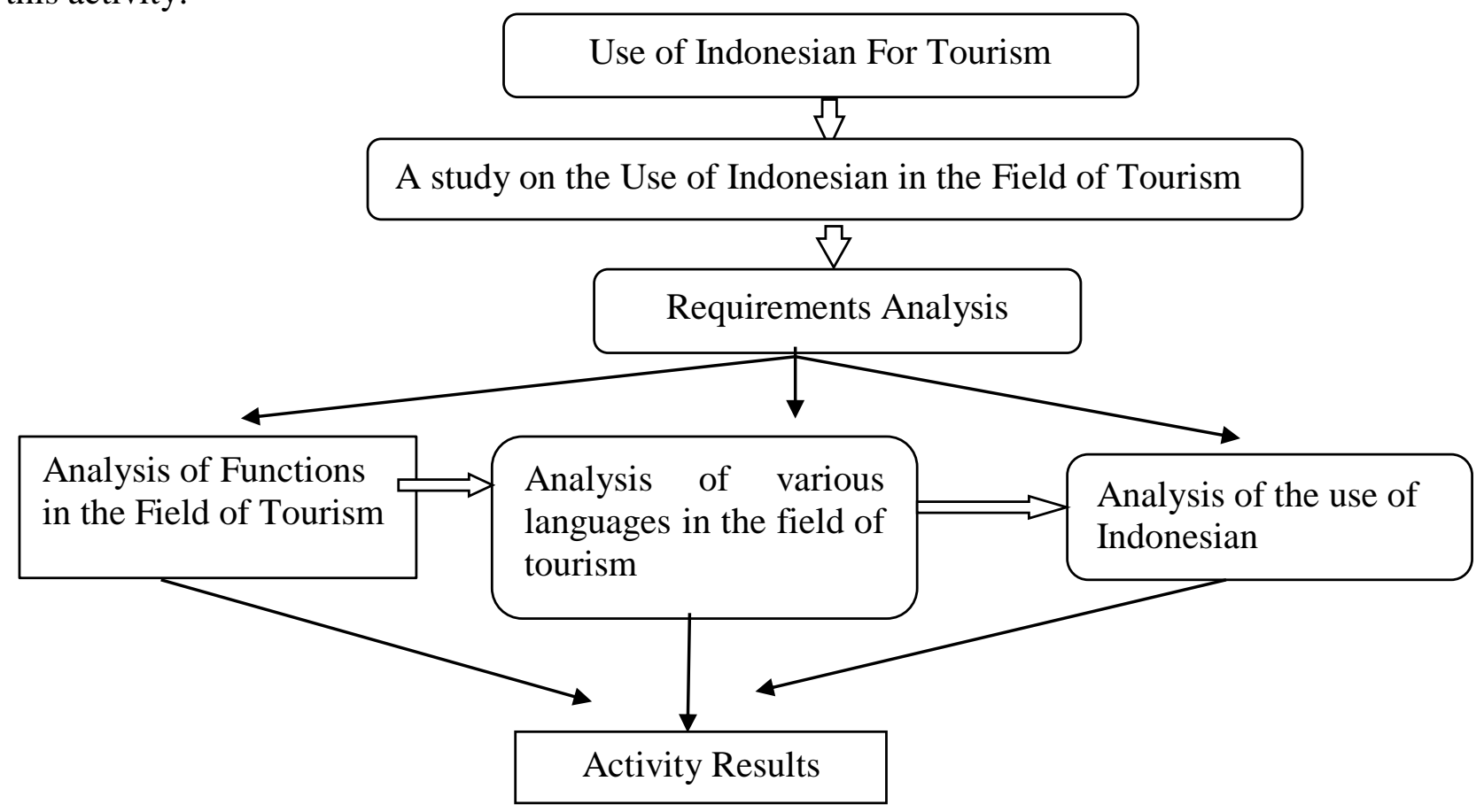

Figure 1. Activity Flow Scheme

\section{Discussion}

In this training, the solution offered is to provide training with chronological strategies. This strategy is carried out by providing training in stages. Starting from the mild to the heavier stages. The training steps will be carried out as follows:

1. The method of implementing the activities carried out in this Indonesian Language use training activity is training and mentoring. The material provided is the concept of good 
and correct language, politeness in language, effective communication, speaking skills. This first stage, provides basic material and assistance that leads to partners to teach employees of the Baubau City tourism office to use good and correct language. After delivering the material, participants were given the opportunity to ask questions.

2. The second stage, the training participants asked questions and answers, this can be done to provide examples of speaking in order to be able to communicate using the concept of politeness in Indonesian language.

3. The third stage of evaluation, this stage is the final stage of training activities. After the participants appeared in front of the forum, an evaluation was immediately held to improve the example of how to use Indonesian by communicating using the concept of Indonesian language that was good and right so that polite and effective communication was achieved. The technical activity is to provide opportunities for participants to give advice and criticize each other for their appearance. At this stage it is expected that partners can provide opportunities for other participants to be able to acquire skills in using polite and effective Indonesian.

A person's creativity in responding to something really determines the acquisition of language, speaking power and behavior that becomes a person's personality also affects a little more variations in language speech.

\section{E. Conclusion}

Ability to use Indonesian Baubau City tourism office employees who tend to use a variety of everyday languages (slang) when talking with guests. This causes a bad image. Good language mastery also determines the future career development of their work, the need for their field of work which specifically must master the language as a means of communication both Indonesian and other foreign languages, the function of the language of tourism is a communicative function in which the Indonesian language used tends to group these functions in the framework of effective communication. While the various languages in the tourism sector tend to vary in non-standard languages, the Indonesian Standard or Standard Languages are not applied in the use of Indonesian in the tourism sector because the standard diversity makes communication ineffective. 


\section{BIBLIOGRAPHY}

Darmawan, Rahmat. (2009). Pembelajaran Bahasa Indonesia Untuk Bidang Pariwisata di Akademi Pariwisata. Program Pascasarjana Universitas Sumatera Utara.

Hardin, Dewi, I. K., Alzarliani, WOD., Azaluddin, Wardana, Andara, D., Ramadhan, F. M., and Huda, AM (2019). The role of communities in conserving mangrove forests to achieve sustainable development. IOP Conference Series: Earth and Environmental Science, 343(1). https://doi.org/10.1088/1755-1315/343/1/012143

Harjito dkk. (2011). Penyuluhan Pembelajaran Bahasa Indonesia Berbasis Intelegensi Natural Pada Guru Paud Non Formal di Kecamatan Gayamsari. Semarang.

Hery Ralph Budhiono. (2017). Keberhasilgunaan Penyulihan Bahasa Indonesia di Kalimantan Tengah. Suar Betang Vol 12. No 1. Hal 83-91.

Saragih, Amrin. (2006). Bahasa Dalam Konteks Sosial. Medan: Program Pascasarjana Universitas Negeri Medan.

Sugondo, D. (2003). Bahasa Indonesia Menuju Masyarakat Madani. Jakarta: Penerbit Progress.

Ulumuddin, dkk. (2017). Penyuluhan Pemerolehan Bahasa Anak bagi Warga Bangetayu Kulon Genuk Semarang Guna Mendukung Kota Layak Anak. Universitas PGRI Semarang. 